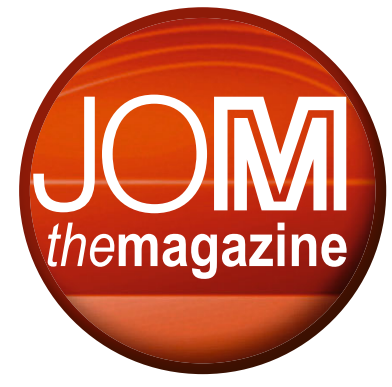

TMS Board of Directors

Stanley M. Howard

President

Professor, South Dakota

School of Mines \&

Technology

Patrice Turchi

Past President

Advanced Metallurgical

Science and Engineering

Group Leader, Lawrence

Livermore National

Laboratory

David H. DeYoung

Vice President

Director, GPP Business

Technology, Alcoa

Joy H. Forsmark

Financial Planning Officer

Technical Expert,

Light Cast Metals,

Ford Motor Company

Amy J. Clarke

Director, Membership \&

Student Development

Scientist, Los Alamos

National Laboratory

\section{Eric N. Brown}

Director, Content

Development \&

Dissemination

Division Leader,

Los Alamos National

Laboratory

\section{Alan A. Luo}

Director/Chair

Light Metals Division

Professor and Director,

Light Metals and

Manufacturing Research

Laboratory,

The Ohio State University

\title{
Building the Global Professional Community: A Priority for the Year Ahead
}

\author{
Stanley M. Howard, 2016 TMS President
}

TMS board motions, minutes, and musings

This regular JOM feature offers news and perspectives on TMS governance, as well as Board of Directors activities, priorities, and decisions. To find out how you can become involved in these initiatives, contact James J. Robinson, TMS executive director, at robinson @ tms.org.

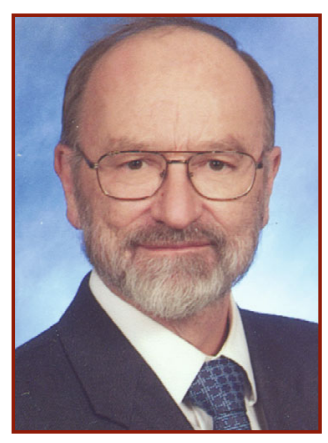

Stanley M. Howard
I remember it vividly, the moment I heard that the Soviet Union had launched Sputnik 1. As a young devotee of space exploration with role models like Werner von Braun and Robert

Goddard, this event propelled me to do something.

I started reading about how to build furnaces for melting glass to make laboratory glassware that I could not afford to buy. Wonderful information was available to me at both the local Carnegie and State of Wyoming libraries, fortuitously close to where I lived in Cheyenne. While exploring glass making, I discovered the world of metallurgical furnaces for smelting and refining metals. This became my passion. I simultaneously built rockets, performed electrolysis of molten salts, and puzzled over phase diagrams. My friends and I were determined to learn what it took to make those wonderful, but frustratingly temperamental, rockets fly.

By early junior high, I had built my own foundry and chemistry laboratory in my parents's basement in a wonderful home; my family was accustomed to hearing the ubiquitous roar of my furnaces. I memorized the Manual of Foundry Shop Practice, not because I had to, but because I loved it so much. To my English teacher's great concern, I wrote all my book reports on metallurgical texts such as The Metallurgy of Copper. By direct order, I took a brief diversion-Hemingway's blessedly short Old Man and the Sea-and then proceeded once again with important reading: Metallurgical Engineering Problems by Allison Butts.

I want to stress, however, that if it were not for the many, many people along the way who showed me the thoroughfares through the technical world, I would still be slowly carving out trails through little patches of treacherous technical real estate.

I was blessed with supportive parents (who also paid the natural gas bills for my furnaces) and wonderful, committed teachers to whom I am continually grateful. But, my most formative moments were the interactions that I had with people who knew metallurgy and chemistry. As a boy, I would travel with my mother to Denver and hang out at the foundry supply store or the chemical supply house while she went about her business. I was full of questions and those kind folks generously engaged me. I am so grateful to them, because they made practical connections not found in even Carnegie's glorious library.

Those types of experiences - connecting with people who could help me take the next step - have always been and will continue to be of tremendous value to me. Most of these connections have been made possible through my involvement with TMS.

I first joined TMS in 1965 as a junior. Later, as a graduate student at the Colorado School of Mines, my thesis advisor, John Hager, made sure I became involved with TMS committees and submitted abstracts for presentations. I would never have been involved with TMS in the way that I am without his mentoring. I have seen this play out with other members countless times since. Building community by being generous with our time, mentoring college students, and encouraging and opening 
doors for our colleagues - especially our young and diverse colleagues - are very rewarding and essential practices for continued TMS relevance and vitality.

Our membership's collegial, grass roots culture is the lifeblood of TMS and my intent as president is to continue building on that unique strength. We share, as TMS members, the wealth of our knowledge and experience. We hold an interest in paving youth's way with the ultimate material of our profession: information. We have joined as colleagues to move efficiently and confidently into new places and recast the old places. It is we who write the papers, texts, books, and articles and we who make the presentations and post the video clips that inform and extend the collective member mind and intrigue the youth destined to join our caravan. We are simultaneously mentors, ambassadors, and explorers.

The important work that we do as TMS members, I believe, is greatly facilitated by the society's strategic goals set by the Board of Directors (see sidebar article). I am particularly excited about the work that TMS is doing in expanding our international outreach. These initiatives help ensure meaningful participation in TMS by professionals and students throughout the world, while addressing vital current opportunities. Developing collaborative relationships with global partners to effectively serve constituents outside of the United States is essential to TMS's leadership role in the global minerals, metals, and materials community. Such relationships do not happen overnight, and I commend the TMS presidents who came before me, as well as each valued meeting organizer and other participants in the process, for their commitment and diligence to this effort. I am looking forward to reporting on TMS's future endeavors in this area in the coming months.

Another priority that I have as president is to continue supporting the progress that TMS has made in offering enriched professional development opportunities to its members. The efforts of the ad hoc Professional Development Committee has allowed TMS to markedly increase its number of short courses, while diversifying content and delivery systems. These programs generally focus on practical information that can be quickly implemented in the work world. I am interested in taking this a step further and applying these principles to smooth the transition of student Material Advantage members to professional status by helping them better understand the value of professional society involvement to their careers.

I have other ideas on ways to enhance the TMS volunteer experience, while advancing our strategic goals. Mostly, my focus will be trying to give back what I have gained from TMS by ensuring that it is a welcoming professional home to all — a place where anyone, from anywhere, at any point in their career can find inspiration, collegiality, shared passion, and either answers to their questions or colleagues who will join with them in the search for answers.

\section{TMS Strategic Goals Provide a Framework for Progress}

The 2018 TMS Strategic Plan, adopted by the TMS Board of Directors in 2014, will continue to guide the society's decision-making, development, and growth under Stanley Howard's leadership as the 2016 TMS president. To read an outline of the plan, visit www.tms.org/society/strategic_plan.aspx. The 2018 TMS strategic goals are listed below as a quick review of the guideposts for the society's future directions.

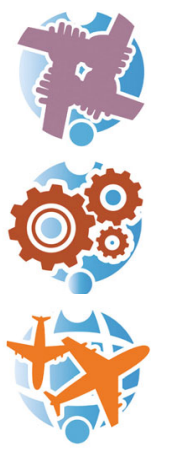

Advance diversity and inclusion

in the minerals, metals, and materials professions.

Accelerate industrial engagement in TMS.

Globally expand the portfolio of TMS international activities.
Advance materials solutions for energy and environmental challenges.

Be the natural home and advocate for materials and manufacturing innovation.
TMS Board of Directors

Jeffrey Fergus

Director, Professional

Development

Professor, Auburn University

Corbett C. Battaile

Director/Chair

Materials Processing \&

Manufacturing Division

Principal Member of

Technical Staff,

Sandia National Laboratory

Edward D. Herderick

Director, Public \&

Governmental Affairs

Additive Technologies

Leader, GE Corporate

Ellen K. Cerreta

Director/Chair

Structural Materials

Division

Group Leader,

Los Alamos National

Laboratory

Srinivas Chada

Director, Programming

Component Packaging

Engineer,

Schlumberger HFE

Roger Narayan

Director/Chair

Functional Materials

Division

Professor

University of North

Carolina and North

Carolina State University

Mark E. Schlesinger

Director/Chair

Extraction \& Processing

Division

Professor, Missouri

University of Science and

Technology

James J. Robinson

Secretary

TMS Executive Director 